\title{
Mycotoxin Contamination in Conventional and Organic Animal Products
}

Alvito, P.C., Sizoo, E.A., Almeida, C.M.M., Van Egmond, H.P., 2010: Occurrence of aflatoxins and ochratoxin $\mathrm{A}$ in baby foods in Portugal. Food Analytical Methods 3, 22-30. doi: https://doi. org/10.1007/s12161-008-9064-x (90).

Armorini, S., Altafini, A., Zaghini, A., Roncada, P., 2016: Occurrence of aflatoxin $\mathrm{M}_{1}$ in conventional and organic milk offered for sale in Italy. Mycotoxin Research 32, 237-246. doi: https://doi. org/10.1007/s12550-016-0256-8 (558).

Food Standards Agency, 2001: Survey of milk for mycotoxins. Food-Survey-Information-Sheet No. 17/01 (208).

Food Standards Agency, 2002: Survey of nuts, nut products and dried tree fruits for mycotoxins. Food-Survey-Information-Sheet No. 21/02 (9).

Gazzotti, T., Lugoboni, B., Zironi, E., Barbarossa, A., Serraino, A., Pagliuca, G., 2009: Determination of fumonisin $B_{1}$ in bovine milk by LC-MS/MS. Food Control 20, 1171-1174. doi: https://doi. org/10.1016/j.foodcont.2009.02.009 (442).

Ghiasian, S.A., Maghsood, A.H., Neyestani, T.R., Mirhendi, S.H., 2007: Occurrence of aflatoxin $M_{1}$ in raw milk during the summer and winter seasons in Hamedan, Iran. Journal of Food Safety 27, 188-198 (294).

Ghidini, S., Zanardi, E., Battaglia, A., Varisco, G., Ferretti, E., Campanini, G., Chizzolini, R., 2005: Comparison of contaminant and residue levels in organic and conventional milk and meat products from northern Italy. Food Additives and Contaminants 22, 9-14. doi: https://doi.org/10.1080/02652030400027995 (295).

Gilbert, J., Shepherd, M.J., 1985: A survey of aflatoxins in peanut butter, nuts and nut confectionery products by HPLC with fluorescence detection. Food Additives and Contaminants 2, 171-183 (18).

Gutiérrez, R., Rosell, P., Vega, S., Pérez, J., Ramírez, A., Coronado, M., 2013: Self and foreign substances in organic and conventional milk produced in the eastern region of Mexico. Food and Nutrition Sciences 4, 586-593. doi: https://doi.org/10.4236/ fns.2013.45076 (421).

Jørgensen, K., 1998: Survey of pork, poultry, coffee, beer and pulses for ochratoxin A. Food Additives and Contaminants 15, 550-554 (102).
Pattono, D., Gallo, P.F., Civera, T., 2011: Detection and quantification of ochratoxin A in milk produced in organic farms. Food Chemistry 127, 374-377. doi: https://doi.org/10.1016/j.foodchem.2010.12.051 (224).

Pozzo, L., Cavallarin, L:, Nucera, D., Antoniazzi, S., Schiavone, A., 2010: A survey of ochratoxin A contamination in feeds and sera from organic and standard swine farms in northwest Italy. Journal of the Science of Food and Agriculture 90, 1467-1472. doi: https:// doi.org/10.1002/jsfa.3965 (498).

Skaug, M.A., 1999: Analysis of Norwegian milk and infant formulas for ochratoxin A. Food Additives and Contaminants 16, 75-78 (316).

Virdis, S., Corgiolu, G., Scarano, C., Pilo, A.L., De Santis, E.P.L., 2008: Occurrence of aflatoxin $M_{1}$ in tank bulk goat milk and ripened goat cheese. Food Control 19, 44-49. doi: https://doi. org/10.1016/j.foodcont.2007.02.001 (31) (intensive versus extensive husbandry system).

Yoon, B.R., Hong, S.-Y., Cho, S.M., Lee, K.R., Kim, M., Chung, S.H., 2016: Aflatoxin $M_{1}$ levels in dairy products from South Korea determined by high performance liquid chromatography with fluorescence detection. Journal of Food and Nutrition Research $55,171-180$ (561).

\section{Mycotoxin Contamination in Organic Animal Products}

Kos, J., Levic, J., Duragic, O., Kokic, B., Miladinovic, I., 2014: Occurrence and estimation of aflatoxin $\mathrm{M}_{1}$ exposure in milk in Serbia. Food Control 38, 41-46 doi: https://doi.org/10.1016/j.foodcont.2013.09.060 (468).

Mortimer, D.N., Shepherd, M.J., Gilbert, J., Morgan, M.R.A., 1987: A survey of the occurrence of aflatoxin $B_{1}$ in peanut butters by enzyme-linked immunosorbent assay. Food Additives and Contaminants 5, 127-132 (52).

Turcotte, A.-M., Scott, P.M., Tague, B., 2013: Analysis of cocoa products for ochratoxin A and aflatoxins. Mycotoxin Research 29, 193-201. doi: https://doi.org/10.1007/s12550-013-0167-x (16). 